\title{
The Intoxicant as Preservative and Scientific Instrument in the World of James Petiver
}

\author{
Kathryn James \\ Beinecke Library, Yale University, USA \\ Email: kathryn.james@yale.edu
}

\begin{abstract}
This article examines the emergent use of alcohol as a preservation medium for scientific specimens from the mid-seventeenth century in Britain. Taking the work of the London apothecary James Petiver (1660-1718) as its focus, the article explores the ways in which alcohol was used to fix and remediate the specimen, shown 'lifelike' in glass, in displays or in engravings. Petiver actively promoted the use of pickling spirits, publishing instructions on how to preserve specimens and distributing these to his collecting agents in the Indies trade. The article introduces the early history of preservation in alcohol in England, and particularly the work of Robert Boyle in promoting the wet collection. It then follows Petiver's agent, Richard Bradley, on his 1711 visit to Leiden and Amsterdam, examining the role of alcohol alongside other means of preserving and activating the scientific collection.
\end{abstract}

In June 1711, James Petiver travelled to Holland as Hans Sloane's agent, acting as his representative in the sale of the botanist Paul Hermann's collection of natural historical specimens. A London apothecary and natural historian, Petiver was the overseer of the Chelsea Physic Garden, a Fellow of the Royal Society of London, and a prominent figure in British medical and natural historical circles. From his premises at the sign of the White Cross on Aldersgate Street, he oversaw a correspondence extending across Britain, Europe, and the West and East Indies trade. He assiduously cultivated correspondents, acting to

\footnotetext{
(C) The Author(s), 2021. Published by Cambridge University Press. This is an Open Access article, distributed under the terms of the Creative Commons Attribution-NonCommercial-ShareAlike licence (http://creativecommons.org/licenses/by-nc-sa/4.0), which permits non-commercial re-use, distribution, and reproduction in any medium, provided the same Creative Commons licence is used to distribute the re-used or adapted article and the original article is properly cited. The written permission of Cambridge University Press must be obtained prior to any commercial use.
} 
place Scottish and other medical apprentices in the Indies trade, while instructing and encouraging collectors in his network. ${ }^{1}$

Despite his extensive correspondence, Petiver was himself a cautious and infrequent traveller. The trip was one of few occasions when he left London, let alone England, lured by the sale of Hermann's collection by his widow. A sale catalogue publicized the extent of the collection, drawn from Hermann's oversight of the Leiden Physic Garden and its connections with the Indies trade, and detailing the 'exotics', animal and vegetable, some preserved 'in liquore Balsamico'. ${ }^{2}$ Petiver embarked in the first week of June for Leiden. 'Last night (I thank God) I came safe and with very good company to Harwich where we found the town full of passengers bound for Holland', he reported to his patron and colleague, sloane. 'We are now very busy in laying in our stores of provision although we hope for a quick passage \& that we may be in Holland tomorrow. ${ }^{3}$

Petiver took the occasion of his trip to draft an informal will, naming sloane as his executor. To Sloane, his fellow collector, Petiver bequeathed 'all my collections of naturall things whatsoever ... and all my manuscripts relating thereto'. He envisioned a series of additional bequests, to be funded by the sale of his printed books. He asked that $£ 100$ be left towards 'the discovery and collecting natural productions', to be kept in the museum of the Royal Society of London. A further $£ 100$ was earmarked for the Chelsea Physic Garden, overseen by the Society of Apothecaries. This bequest was intended not only to fund collections, but to 'encourage and promote the monthly botanic herbarizings \& lectures of botany'. Petiver imagined his bequests in great detail, outlining an administrative structure, detailing its oversight by a committee formed by Sloane and the Royal Society, and choosing apothecaries to manage the garden. ${ }^{4}$

What did it mean to be preserved in liquore Balsamico? When Thomas Browne described balsam in his Hydriotaphia: urne-buriall (1658), it was

\footnotetext{
${ }^{1}$ On Petiver, see Raymond Phineas Stearns, 'James Petiver, promoter of natural science, c. 16631718', Proceedings of the American Antiquarian Society, 62 (1952), pp. 243-365; also David Allen, 'Petiver, James (c. 1665-1718)', ODNB. Recent studies on aspects of Petiver's collections include Kathleen S. Murphy, 'Collecting slave traders: James Petiver, natural history, and the British slave trade', William and Mary Quarterly, 70 (2013), pp. 637-70; Anna Marie Roos, “'Only meer love to learning": a rediscovered travel diary of naturalist and collector James Petiver (c. 1665-1718)', Journal of the History of Collections, 29 (2017), pp. 381-94; K. A. James, '"Humbly dedicated": Petiver and the audience for natural history in early eighteenth-century Britain', Archives of Natural History, 31 (2008), pp. 318-29. Hans Sloane (1660-1753) was a physician, natural historian, and collector, who, through his posthumous gift, helped to establish the British Museum. On Sloane, see most recently James Delbourgo, Collecting the world: Hans Sloane and the origins of the British Museum (Cambridge, MA, 2017); Alison Walker, Arthur Macgregor, and Michael Hunter, eds., From books to bezoars: Sir Hans Sloane and his collections (London, 2012); Arthur Macgregor, ed., Sir Hans Sloane: collector, scientist, antiquary, founding father of the British Museum (London, 1994).

${ }^{2}$ Catalogus musei indici continens varia exotica, tum animalia, tum vegetabilia, nativam figuram servantia, singula in liquore balsamico asservata (Leiden, 1711).

${ }^{3}$ James Petiver to Hans Sloane, 7 June 1711, Harwich, British Library (BL), Sloane MS 4042, fo. $295 \mathrm{r}$.

${ }^{4}$ BL, Sloane MS 4042, fo. 296.
} 
metaphorically, for the 'noble acts, which are the balsame of our memories' ${ }^{5}$ Balsam was used in this general sense to refer to a preserving balm, the usages of which encompassed a broad range of meanings from the metaphorical - the 'balsamic', the 'balm of Gilead' - to medical balms to heal and preserve the body, to alchemical and magical agents of preservation. What Petiver, as an apothecary, described as 'balsamic liquor' could easily be taken by his readers to refer to a broad category of preservation agents, from the liquid dripping from mummies, to medical prescriptions, to the recipes used to stabilize wet collections, keeping the still fleshy natural historical or anatomical specimens intact and resistant to decay. ${ }^{6}$

By the early eighteenth century, the wet collection was a mark of virtuosity, often displayed in glass containers, housed in glass-fronted cabinets. Alcohol was useful as a means to transport specimens from the point of collection, and also acted as an important mechanism of long-term preservation and display. As a preservation agent, 'liquore Balsamico' became particularly desirable when used in the newly available jars of clear flint glass, commercially produced in England from at least 1673. ${ }^{7}$ Preserved in alcohol and housed in glass, the specimen became at once stable and dazzlingly visible.

This article highlights the fact that, alongside its other roles in the early modern British empire, alcohol was an active force in imperial scientific culture in its role as medium of preservation and display. Petiver's collecting depended on the Indies trade, and on his ability to enlist medical apprentices and other skilled, ship-bound collectors as his agents, following his instructions on how to collect and preserve natural historical commodities. ${ }^{8}$ The rum and arrack that Petiver recommended to his agents in the Indies trade were used, in turn, as fixing agents for collections sustained by that trade, preserving and displaying these specimens for an audience of the curious in Britain and Europe. In this particular context, and distinct from its role in those other spheres of production and consumption discussed in this issue, alcohol acted as a medium, a means by which the specimen was activated for its audiences, presented in its 'lifelike' form. ${ }^{9}$ Preserved in spirits, housed

\footnotetext{
5 'Balsam = balm', Oxford English dictionary.

${ }^{6}$ On wet collections as part of the history of the discipline of museum preservation, see John E. Simmons, Fluid preservation: a comprehensive reference (London, 2014).

${ }^{7}$ Robert Hooke recorded a visit to a new glasshouse, owned by George Ravenscroft, on 29 July 1673; in 1674, Ravenscroft was awarded a patent for the 'Art and manufacture of a perticular sort of christaline glasse resembling rock christall, not formerly exercised or used in this our kingdome'. See Michael Noble, 'The "invencon" of lead crystal - or was it flint glass?', Journal of Glass Studies, 58 (2016), pp. 185-95, at pp. 185-7. See also Charles Orser, An archaeology of the British Atlantic world, 1600-1700 (Cambridge, 2018).

${ }^{8}$ Kathryn James, "'Curious Scotch plants": Scotland as the exotic in the Edinburgh physic garden', Lumen, 24 (2005), pp. 135-48.

${ }^{9}$ Lisa Gitelman, Always already new: media, history, and the data of culture (Cambridge, MA, 2006), p. 5, describes media as comparable to 'the scientific instrument of a society at large'. In doing so, Gitelman gestures to the work of Simon Schaffer and Stevin Shapin: in the air pump as instrument, she finds a parallel for media, defined as 'socially realized structures of communication, where structures include both technological forms and their associated protocols, and where communication is a cultural practice' (p. 7). See Stevin Shapin and Simon Schaffer, Leviathan and the air-pump:
} 
in glass, and viewed in the cabinet or the copperplate engraving, the natural historical specimen was a persuasive and mobile form of scientific evidence.

As the articles in this issue argue, intoxicants underpinned European global expansion and expropriation: as staples driving the profits of colonial ventures (as in the case of tobacco and sugar) or as commodities framing exchanges with indigenous peoples or the 'welfare' of European planters and soldiers (as in the case of alcohol). When used as a preservative, however, alcohol facilitated European imperialism of a different kind: the seizure and transportation of foreign creatures and their re-categorization as the performative specimens of a Western natural historical system of classification by which that same imperial epistemic and geographical expansion was justified. When alcohol worked as a preservation medium, it activated the specimen of empire in 'lifelike' form. ${ }^{10}$

This article takes Petiver's and his agents' interaction with their natural historical colleagues in Leiden and Amsterdam as its particular focus, asking what qualities made preservation in alcohol particularly persuasive for collectors and consumers. Petiver's published instructions to his collectors offer insight into the practices of collecting, as well as the expectations that governed the reception and publication of specimens once they had reached the patron. The article turns to the early history of preservation in alcohol in England, and particularly the work of Robert Boyle in promoting the wet collection. It then follows Petiver's agent, Richard Bradley, on his visit to Leiden and Amsterdam in 1711, examining the 'lifelike' qualities that preservation in alcohol was meant to grant its subject. Alcohol bestowed qualities on specimens that rendered them more persuasive as instruments of scientific evidence, particularly when the specimen was made present through copperplate engravings in published catalogues or treatises.

\section{II}

In 1711, Leiden was one of the centres of the natural historical world, and the sale of Paul Hermann's collection a celebrity highlight. Since its founding in 1594 under the direction of Charles de l'Escluse (or Clusius), the physic garden had been known as one of the key natural historical collections. Some 1,585 plant names were listed in the first catalogue of the garden's contents, the

\footnotetext{
Hobbes, Boyle, and the experimental life (Princeton, NJ, 1985). As influences on this definition, Gitelman cites Geoffrey C. Bowker and Susan Leigh Star, Sorting things out: classification and its consequences (Cambridge, MA, 1999); James Carey, Communication as culture: essays on media and society (Boston, MA, 1989).

${ }^{10}$ This article draws particularly on the work of Harold Cook, Londa Schiebinger, Emma Spary, and others on the intersections of natural history and European imperial expansion, and especially on H. J. Cook, Matters of exchange: commerce, medicine, and science in the Dutch golden age (New Haven, CT, 2007); Londa Schiebinger and Claudia Swan, eds., Colonial botany: science, commerce, and politics in the early modern world (Philadelphia, PA, 2005); Londa Schiebinger, Plants and empire: colonial bioprospecting in the Atlantic world (Cambridge, MA, 2004); E. C. Spary, Utopia's garden: French natural history from Old Regime to revolution (Chicago, IL, 2000); N. Jardine, J. A. Secord, and E. C. Spary, eds., Cultures of natural history (Cambridge, 1996); H. A. Curry, N. Jardine, J. A. Secord, and E. C. Spary, eds., Worlds of natural history (Cambridge, 2018).
} 
Index stirpium of $1594-5 .^{11}$ The garden itself (alongside the anatomy theatre, university library, and fencing school) was the subject of one of four engraved plates, published in 1610 and appearing in copies in other works. ${ }^{12}$

By 1711, when Petiver visited, some 3,700 plants had been listed in the most recent catalogue of the garden's contents. ${ }^{13}$ The Leiden Physic Garden had a long history of friendship with the Chelsea Physic Garden, following Hermann's visit to London in $1682 .{ }^{14}$ Hermann had served with the Dutch East India Company, forming collections in Sri Lanka. He ended as the professor of botany at the University of Leiden, where he oversaw the medical garden. His extensive specimen collections came up for auction in 1711, several years after his death in 1695.

With his characteristic eye for detail, Petiver offers an account of the sale in a letter to Sloane. At eight in the morning, he writes, he went to Madame Hermann's auction,

which began at $9 \&$ by twelve a clock, they sold to the bottom of page 13 . \& the afternoon between $2 \& 4$ they went through all the animals \&c preserved in spirits \& glasses to no 342 .

I was present all the while \& have bought you the greatest share of the choicest of them; your potent antagonists were my heer Koeglaer [the apothecary Frans Kiggelaer], the learned Gronovius, his son [presumably Jacobus Gronovius and his son, the botanist Jan Frederick Gronovius], Mr Cuthbert an Irish gentleman \& a famous painter of this university whose name I have at present forgot: never the less I hope I have bought you pretty good pennyworths, which I give you a list to judge of by the prices I have annexed underneath to their numbers. ...

I verily believe the whole sold not for what the spirits \& glasses cost. ${ }^{15}$

'Spirits \& glasses' were an important mechanism by which collections were made visible, rendered immediate to their audiences. As a fixing agent, alcohol enabled preservation within any container: jarred specimens figure regularly in inventories of late seventeenth- and eighteenth-century collections, alongside accounts of the cost of the spirits and the jars themselves. ${ }^{16}$ Yet as the

\footnotetext{
${ }^{11}$ Kaspar van Ommen, The exotic world of Carolus Clusius (1526-1609) (Leiden, 2009), p. 21. On the Leiden Physic Garden under Clusius, see Florike Egmond, The world of Carolus Clusius: natural history in the making, 1550-1610 (London, 2010).

${ }^{12}$ Harm Beukers, 'Studying medicine in Leiden in the 1630s', in Kathryn Murphy and Richard Todd, eds., A man very well studyed: new contexts for Thomas Browne (Leiden, 2008), pp. 49-64, at p. 52.

${ }^{13}$ Hermann Boerhaave compiled an Index for the garden in 1710. Penelope Hunting, 'Isaac Rand and the Apothecaries' Physic Garden at Chelsea', Garden History, 30 (2002), pp. 1-23, at p. 2.

${ }^{14}$ Elizabeth Den Hartog and Carla Teune, 'Gaspar Fagel (1633-88): his garden and plant collection at Leeuwenhorst', Garden History, 30 (2002), pp. 191-205, at p. 195. For more on the intersections of Dutch and English natural historical collecting and cultivation of exotic specimens, see David Jacques and Arend Jan van der Horst, The gardens of William and Mary (London, 1988).

${ }^{15}$ Petiver to Sloane, 18/29 June 1711, Leiden, BL, Sloane MS 4042, fo. 305r.

${ }^{16}$ Sachiko Kusakawa, 'William Courten's lists of “Things bought” from the late seventeenth century', Journal of the History of Collections, 29 (2017), pp. 1-17. Kusakawa's online appendix (https://doi. org/10.1093/jhc/fhv040) lists a painstaking transcription of Courten's accounts, in which he
} 
medium for display specimens, shown 'lifelike' in glass in collections or engravings, alcohol also acted as a persuasive or rhetorical instrument. In this capacity, as an agent of translation, it assisted in the performance of a particular type of identity, one in which the biological commodity was made to act as a specimen, ontologically resituated within the imperial epistemic project of natural history.

Petiver had issued one of the first practical guides to collecting specimens. His printed broadside with instructions - the Brief directions for the easie making and preserving collections of all natural curiosities (1709?) - was one of several he produced to instruct collectors in the tools and methods for gathering useful specimens. ${ }^{17}$ In this practical guide, he emphasized the care required in collecting and transporting useful specimens. Humidity and damp, jostling, and breakage were only a few of the hazards to the travelling specimen. Specimens were instruments, acting as iterations of an abstract natural historical concept. Like an imperfect copy of a book, they could fail to transmit their identity to their audiences. The too partial or fragmented specimen; one that was inadequately or incorrectly identified; one that was confused with other specimens or collected without contextual identification: these could fail as instruments of natural historical representation. At their most valuable, however, specimens survived intact, readily identifiable within the context of the collector's own specimen garden, collection, or reference works. Petiver's own collections were extensive and notoriously disorganized, his obsessiveness as collector and correspondent leading him to acquire both entire specimens and their cut-rate counterparts, the bits of flower, leaf, coral, or mollusc that might extend his collection but prove entirely unidentifiable. ${ }^{18}$

The Brief directions is one of the first guides to recommend the use of spirits for preservation. Petiver begins by directing collectors to keep 'All small Animals or Beasts, Birds, Fishes, Serpents, Lizards, and other Fleshy Bodies

itemizes both specimens and his expenses on collecting materials. As an example, in the 'Things bought in January, February, March \& April 1690', Courten lists items bought 'Of Mr Gidley', including a Philip and Mary shilling (2s 6d), a 'young Tea fruit', two 'Serpents hornes Dr Walraven f. \& turned' (1s), a 'Bird from the West Indies', a 'ps of Ivory used in the Indies on there [sic] armes when they draw their bowes', a 'moth with the Aurelia', and nineteen 'Barbadoes seeds g. by Mr Chamberlaine Jun'. Courten also acquired eleven 'Corkes for bottles for my Insects at $2 \mathrm{~d}$ ps', eleven 'flint glasses, 3 verry large 8 indifferent large' ( $£ 115 \mathrm{~s})$, six lots of ' 4 small glasses 2 small rummers' (1s); one 'gallon spirit of wine for the serpens puturius' (6s); and three 'quarts spirit of wine for the others' (4s 6d). See Kusakawa, 'William Courten's lists', appendix 1, p. 22, citing BL, Sloane MS 3961, fo. $40 \mathrm{v}$.

${ }^{17}$ James Petiver, Brief directions for the easie making, and preserving collections of all natural curiosities. For James Petiver Fellow of the Royall Society ([London], [1709]). On Petiver's collecting, see Charles Jarvis, “Take with you a small spudd or trowell": James Petiver's directions for collecting natural historical curiosities', in Arthur MacGregor, ed., Naturalists in the field: collecting, recording and preserving the natural world from the fifteenth to the twenty-first century (Leiden, 2018), pp. 212-39. On the relational network of his collecting, see James, "'Humbly dedicated".

18 'No insects will come amiss ... \& so I can have them cheap I shall not stand upon the loss of a leg or a wing', wrote Petiver to his colleague William Sherard in July 1697. BL, Sloane MS 3333, fos. 26-28, cited from Stearns, James Petiver, pp. 284-5. 
capable of Corruption' in 'Rack, Rum, Brandy; or any other Spirits'. Where spirits were not available, he instructed that sea water or a 'strong Pickle' of brine, salt, and powdered alum should be substituted. 'And so send them in any Pot, Bottle, box, \&c. close stopt, Cork'd and Rosin'd.' Small birds could also be kept in spirits, as could 'all large pulpy moist Fruit, that are apt to decay or rot'. Insects could be 'Drowned altogether, as soon as Caught: in a little wide Mouth'd Glass, or Vial, half full of Spirits, which you may carry in your Pocket'. ${ }^{19}$

While 'Fleshy Bodies capable of Corruption' - animals, birds, fish, snakes, lizards, fruits, and insects - could be preserved in spirits, plants were to be dried. Again, Petiver offers detailed instructions on how to collect, directing his reader to put plant specimens into a 'Book, or Quire of Brown Paper stitch'd (which you must take with you) as soon as gathered'. These were to be periodically moved into 'fresh Books, to prevent either rotting themselves or Paper'. Petiver's instructions came to reflect common practice in the later eighteenth century, as witnessed by the specimens from Joseph Banks's voyage on the Endeavour, preserved in the sheets of an unbound copy of Addison's Notes upon the twelve books of Paradise Lost. ${ }^{20}$

Collectors were expected to gather specimens for dry and wet collections. For herbaria and dried collections, Petiver advised his agents to carry quires of paper in which to collect, a notebook for observations, a trowel to dig roots and specimens, and 'sheets of wast paper to wrap your seeds or fruit in with ... a little packthread and a knife, ${ }^{21}$ For other specimens, he recommended 'drowning' in spirits or brine, carrying a jar of 'strong brine or sea water (which is the best way I can at present think of to preserve their shape and colour)' ${ }^{22}$ He urged his apprentice agents to organize their collections, gathering further parts (leaves, flowers) of a specimen to facilitate later comparison and illustration. ${ }^{23}$

When Petiver issued his instructions for collecting in the 1690s, drowning, or the creation of wet collections, was becoming an established preservation practice. Collectors varied their approach, but the fundamental principles remained consistent: storing specimens in alcohol or sea water in a closed container. Different kinds of alcohol were used: rum, arrack, brandy, spirits of wine, aqua vitae, and others. The natural historian René-Antoine Ferchault de Réaumur advised his colleague to add sugar to diluted spirits of wine:

\footnotetext{
${ }^{19}$ Petiver, Brief directions. On transporting specimens, see especially Christopher M. Parsons and Kathleen S. Murphy, 'Ecosystems under sail: specimen transport in the eighteenth-century French and British Atlantics', Early American Studies, 10 (2012), pp. 503-39.

${ }^{20}$ Natural History Museum, London, MSS Banks collection, 'Madeira III'.

${ }^{21}$ BL, Sloane MS 3332, fo. 3r.

${ }^{22}$ Petiver's notes on the advertisement for and proof copies of the second and third issues ('centuries') of the Musei Petiveriani, in BL, Sloane MS 3330, fos. 172-80. See fo. 179r for Petiver's 'advertisement' for his 'short instructions or an easie method how to preserve these things'. This follows a slightly different order from the printed Brief directions, and seems to have been one of several earlier iterations.

${ }^{23}$ BL, Sloane MS 3332, fo. 3r.
} 
Here is the means: furnish [the servant], sir, if you please, with what I call a 'graveyard', that is to say a large bottle filled with spirits of wine diluted by about a quarter with normal water. Have as much sugar thrown into the liquid as can be dissolved in it ... Your naturalist, equipped with this graveyard, has only to toss into it 4 or 5 insects of all the species he finds, caterpillars, beetles, flies. It will accommodate anything but butterflies. And you can then send me in little bottles whatever you remove from the big graveyard. ${ }^{24}$

Used to 'drown' specimens in the 'graveyard', alcohol acted as an instrument of field preservation, stabilizing and conveying specimens from the point of collection to their receipt by the collecting agent's patron or buyer.

\section{III}

Petiver drew on an existing tradition of pickling as a visual medium in English natural history. He refers his reader to Robert Boyle's General heads for natural history, proposed to travellers and navigators of $1692 .{ }^{25}$ Boyle, an early proponent of preservation of natural historical specimens in alcohol, particularly emphasized the use of spirits of wine as a visual aid. In a letter to the Philosophical Transactions in 1665, he refers to the utility of preserving foetal specimens in spirits of wine, extending this to the observation of eggs. He is explicit in proposing this as a visual device, a mechanism for rendering embryonic formation visible for his own observation and that of his friends:

I remember, I did, when I was solicitous to observe the process of nature in the formation of a chick, open hens' eggs, some at such a day, and some at other days after the beginning of the incubation, and carefully taking out the embryos, embalmed each of them in a distinct glass (which is to be carefully stopped) in spirit of wine: which I did, that so I might have them in readiness, to make on them, at any time, the observations, I thought them capable of affording; and to let my friends at other seasons of the year, see. ${ }^{26}$

Boyle gives instructions on 'imbalming', recommending the addition of sal ammoniac for more developed foetal specimens, and using spirits of wine to wash the specimens when removed from the egg. He discusses the issue of colour and discoloration. And he recommends soaking specimens for several

\footnotetext{
${ }^{24}$ Réaumur to Caumont, 17 Nov. 1736, Fonds Trembley 5, BG, cited in Mary Terrall, 'Following insects around: tools and techniques of eighteenth-century natural history', British Journal for the History of Science, 43 (2010), pp. 573-88, at p. 578.

${ }^{25}$ See Jarvis, "'Take with you a small spudd or trowel”, p. 218. On Nehemiah Grew and Boyle, see Ken Arnold, Cabinets for the curious: looking back at early English museums (Ashgate, 2006), pp. 141-2; on the shift to display of specimens in jars, see Suzanne Anker and Sarah Franklin, 'Specimens as spectacles: reframing fetal remains', Social Text, 29 (2011), pp. 103-25, at p. 104 and n. 2.

${ }^{26}$ Robert Boyle, 'A way of preserving birds taken out of the egge, and other small fætus's; communicated by Mr. Boyle', Philosophical Transactions, 1 (1665-6), pp. 199-201.
} 
hours in 'either the same kind of Spirit, or better', so that the 'Liquor, having drawn as it were what Tincture it could, the Foetus being remov'd into more pure and well dephlegm'd Spirit of Wine, might not dis colour it, but leave it almost as limpid, as before it was put in'.

This letter drew on Boyle's earlier methodology, published in his Some Considerations Touching the Usefulness of Experimental Natural Philosophy (1663). In the mid-seventeenth century, when Boyle first recommended the use of spirits of wine, with its 'balsamic faculty', he emphasized the visual role of the liquid agent: 'for this Liquor being very limpid, and not greasy, leaves a clear prospect of the bodies immersed in it'. ${ }^{27}$ Boyle introduced visual preservation as a property of spirits of wine, describing his experiment with preserving the 'shine' of a rotting fish. ${ }^{28}$

When Petiver emphasized that Paul Hermann's specimens had sold 'not for what the spirits \& glasses cost', he articulated the critical importance of the medium and container to the natural historical specimen's ability to perform itself for its audiences. The container was an essential component of the wet collection. For collecting, as Petiver's instructions indicate, any type of vessel or pot could be used. For display, however, glass played an increasingly important role over the course of the seventeenth century, for the specimen collection as for the microscope, telescope, or other optical technology. In England, the development of flint glass by George Ravenscroft, and its patenting in 1674, led to a radical change in the size, price, and availability of glass displays. Robert Hooke visited Ravenscroft's glasshouse in the Savoy, London, writing about the visit in his diary entry for 29 July $1673 .{ }^{29}$ Boyle's letter on preserving in spirits of wine appeared in the Philosophical Transactions in the company of a review of Hooke's Micrographia. In this, the reviewer argues, 'a new visible world is discovered by this means, and the Earth shews quite a new thing to us'; with the microscope 'we may perhaps be enabled to discern the secret workings of nature, almost in the same manner, as we do those that are the productions of art'..$^{30}$ The 'new visible world' was one increasingly displayed in glass containers, as it was viewed through glass lenses, glass mirrors, glassdoored cabinets, and glass windows. When Petiver described the cost of 'spirits and glasses' at the sale, he was also highlighting the interdependence of the two commodities within the consumer culture of natural history, a point

\footnotetext{
${ }^{27}$ Robert Boyle, Some considerations touching the usefulness of experimental natural philosophy (Oxford, 1663), p. 26.

${ }^{28}$ Ibid., p. 29: 'Nay, we have for curiosity sake, with this Spirit, preserv'd from further stinking, a portion of Fish, so stale, that it shin'd very vividly in the dark; in which Experiment, we also aim'd at discovering whether this resplendent quality of the decaying Fish would be either cherish'd, or impair'd by the Spirit of Wine.'

${ }^{29}$ Noble, “'Invencon" of lead crystal', p. 187. See also Charles Orser, An archaeology of the British Atlantic world, 1600-1700 (Cambridge, 2018).

30 'An advertisement of a way of making more lively counterfaits of nature in wax, then are extant in painting: and of a new kinde of maps in a low relievo; both practised in France', Philosophical Transactions, 1 (1665-6), pp. 99-100; 'An account of micrographia, or the physiological descriptions of minute bodies, made by magnifying glasses', Philosophical Transactions, 1 (1665-6), pp. 27-8.
} 
reinforced by historians of alcohol in the discussions of alcohol consumption and the early modern market for drinking glassware. ${ }^{31}$

\section{IV}

After the sale, Petiver returned to Amsterdam to make spend more time with one of the most influential practitioners of the specimen display, Frederik Ruysch, a Dutch physician and anatomist. Ruysch had become Amsterdam's praelector of anatomy in 1667, a role he energetically assumed, performing over thirty public demonstrations over the course of his career. ${ }^{32}$ From 1685, he was professor of botany at the Hortus botanicus in Amsterdam. ${ }^{33}$ His powerful influence as anatomical demonstrator was documented by Jan van Neck in his painting The anatomy lesson of Dr. Frederick Ruysch (1683). ${ }^{34}$ Ruysch himself publicized his botanical and anatomical collections in his catalogues and serial publications, including the Hortus Amstelodemensis (1697, edited with Frans Kiggelaer), the Thesaurus anatomicus (1701-16), and the Thesaurus animalium (1710).

When Petiver visited in 1711, Ruysch had become famous for his wet collections, the embalmed specimens, human and natural, displayed in glass and often decorated with ornate tableaux formed of the material from other specimens. These tableaux were re-purposed from Ruysch's earlier collections, the predominantly dry collections of specimens that were his primary focus until around $1701 .^{35}$ By the time of Petiver's visit, Ruysch was renowned for the embalmed collections displayed in the Theatrum animalium (1710), with its idealized rendition of the salon in Ruysch's house on the Bloemgracht (Figure 1). Here the collector and his visitor, classically depicted, enact the performance of the collection's demonstration. The collection itself is depicted in some seven standing cabinets, one prominently open to reveal row upon row

\footnotetext{
${ }^{31}$ See, for example, the work of Angela Mcshane, esp. Angela McShane and Nigel Jeffries, 'I say "shard", you say "sherd": contrasting and complementary approaches to a piece of early modern "Venice glass", in Catherine Richardson, Tara Hamling, and David Gaimster, eds., The Routledge handbook of material culture in early modern Europe (London, 2016), pp. 452-65; and Angela McShane, 'Material culture and "political drinking" in seventeenth-century England', Past \& Present, 222, Suppl. 9 (2014), pp. 247-76.

${ }^{32}$ Julie V. Hansen, 'Resurrecting death: anatomical art in the cabinet of Dr. Frederik Ruysch', Art Bulletin, 78 (1996), pp. 663-79, at p. 667.

${ }^{33}$ D. O. Wijnands, The botany of the Commelins (Rotterdam, 1983), p. 212. Petiver to Sloane, 18 June 1711, Leiden, BL, Sloane MS 3322, fo. 305r: 'I have been very civilly received by Dr. Ruysch, who at my return promises me much more; if therefore you please to direct your commands for me to be left with him, I shall soon receive them.'

${ }^{34}$ Ruysch was the subject of several portraits, including Adriaen Backer, Anatomische les van Dr. Frederik Ruysch (1670), Amsterdam Museum (http://am.adlibhosting.com/Details/collect/ 37898), and Jan van Neck, Anatomische les van Dr. Frederik Ruysch (1683), Amsterdam Museum (http://am.adlibhosting.com/Details/collect/37978).

${ }^{35}$ Gijsbert M. van de Roemer, 'From vanitas to veneration: the embellishments in the anatomical cabinet of Frederik Ruysch', Journal of the History of Collections, 22 (2010), pp. 169-86, at pp. 173, 175. On Ruysch, see also Luuc Kooijamns, Death defied: the anatomy lessons of Frederik Ruysch, trans. Diane Webb (Leiden, 2011).
} 


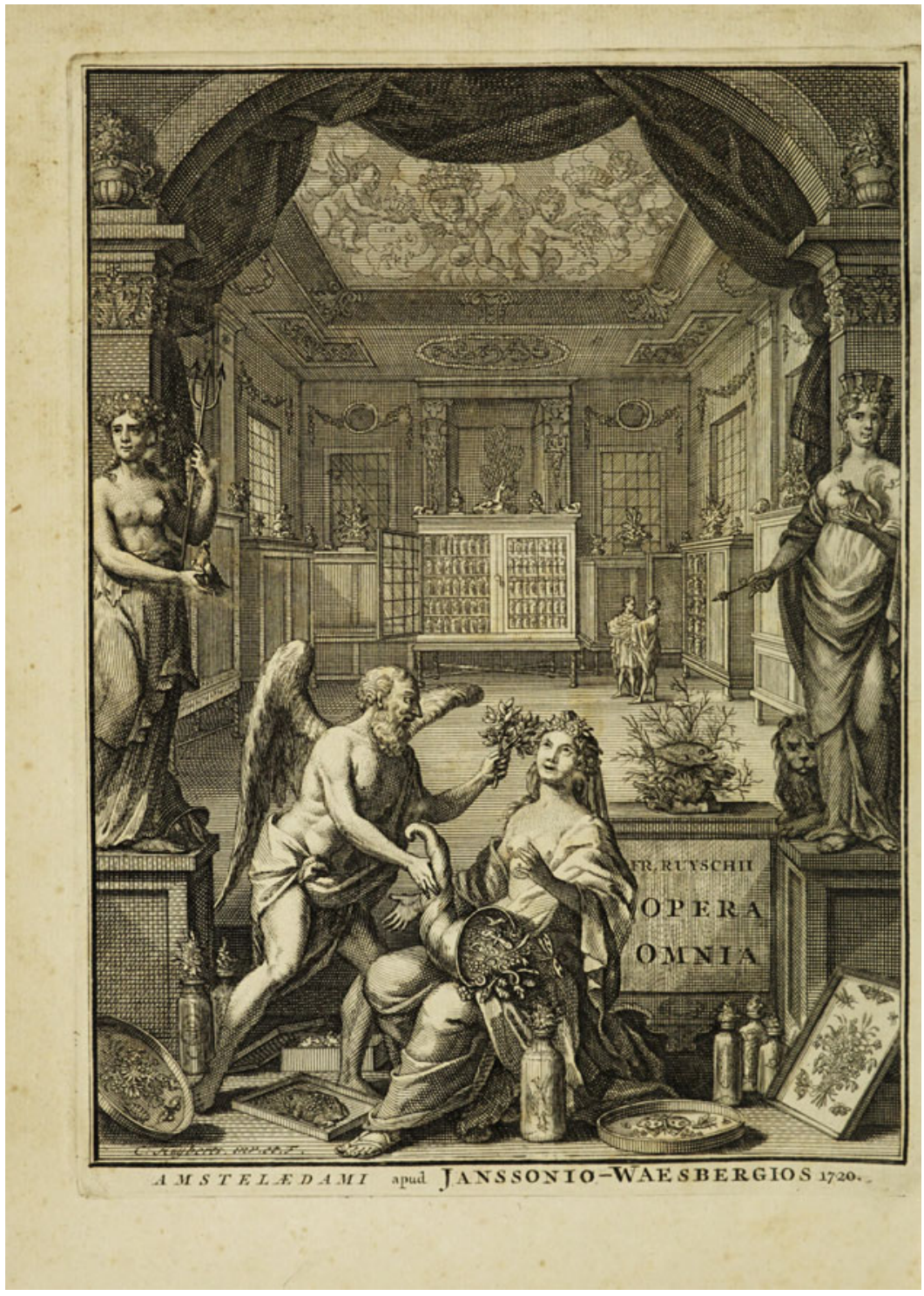

Figure I. Specimens displayed in glass jars, in glass-fronted cabinets in Ruysch's representation of his house museum.

Source: Frederik Ruysch, Opera omnia anatomico-medico-chirurgica, vol. I (Amsterdam, [1725]), frontispiece. From the collections of the Wellcome Library.

of neatly displayed glass jars, their contents too remote to view. The specimens themselves appeared in the Theatrum animalium in a series of engraved tables (Figure 2). Ruysch's daughter Rachel, an accomplished botanical artist, constructed many of the tableaux of shells, eggs, gallstones, blood vessels, 


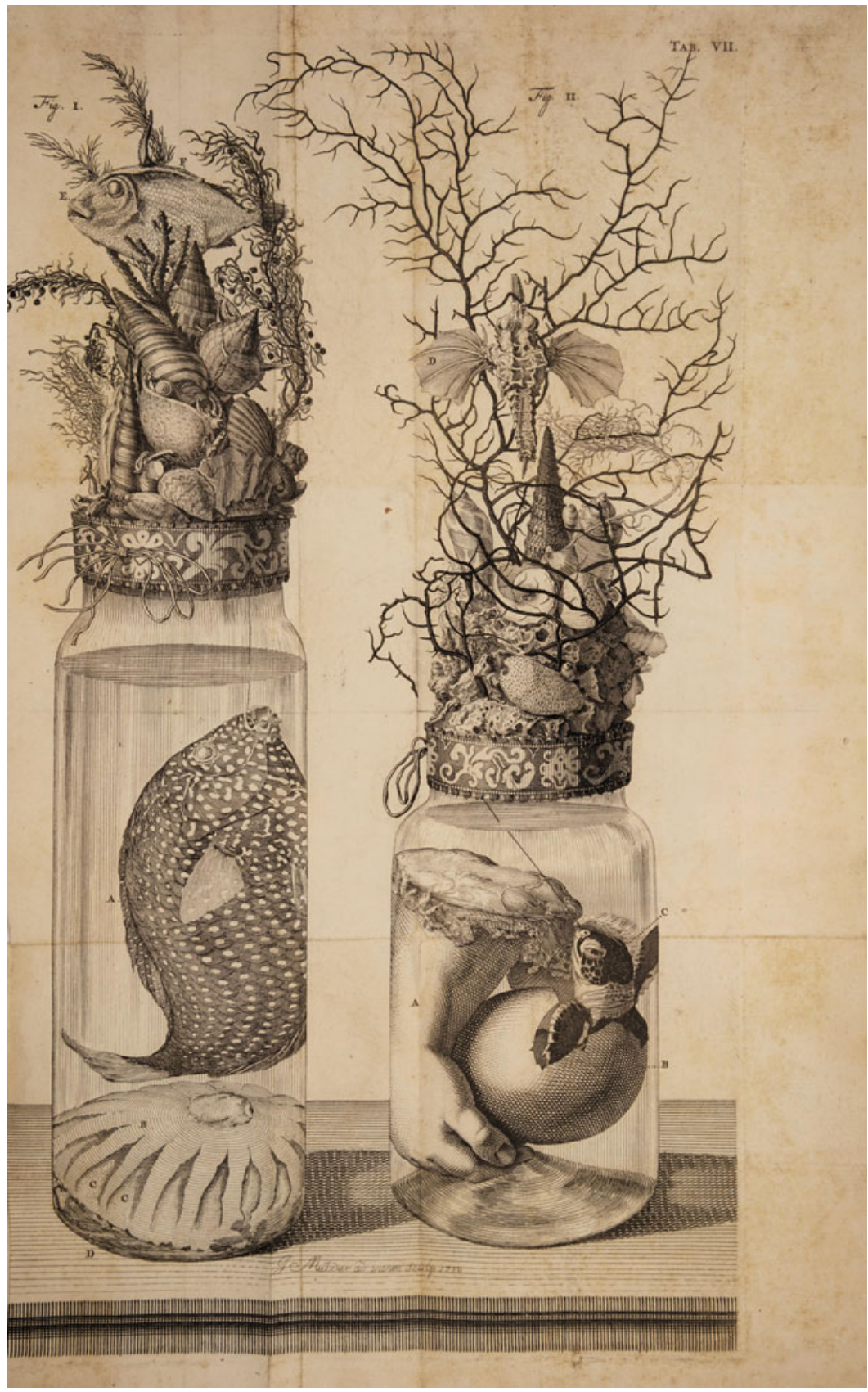

Figure 2. An engraved table depicting Ruysch's carefully arranged specimens, preserved in 'balsamic liquor' and displayed in glass.

Source: Frederik Ruysch, Thesaurus animalium primus (Amsterdam, 1710), table VII. From the collections of the Wellcome Library. 
skeletons, lace, caps, feathers, and cuffs by which specimens were sometimes ornamented. ${ }^{36}$

While Ruysch showed his collection to visitors such as Petiver, it was primarily through the medium of print that the embalmed specimens and the collection they represented reached a broader virtuosic audience. ${ }^{37}$ Some features of his technique, such as the specimens' vivid retention of colour, were highlighted by correspondents and visitors but only manifested in print if added through hand-colouring of an individual engraving. Engaged for at least a decade in trying to sell his collection, Ruysch was reluctant to reveal his embalming technique. The Scottish surgeon Archibald Adams, writing to Sloane in 1707, informed him of Ruysch's willingness - if sloane or any 'British subject, corporation or college' were to acquire the collection - to 'make me as perfect as himself in the art of embalming, injecting \& preserving in animated bodys'. $^{38}$

In May 1714, some three years after his patron's visit, Richard Bradley travelled to the Netherlands as Petiver's agent. Writing with characteristic buoyancy, and under a false name and credentials, he said of his first visit to Ruysch in Amsterdam that "tis with Difficulty (notwithstanding my great skill in opticks) that I had hitherto preserv'd my eyesight, the Darling Beauties of those Cabinets I have seen are sufficient to blind the World'. ${ }^{39}$ Bradley had tremendous admiration for Ruysch's collection, which he observed in between his labours in the Amsterdam Physic Garden, collecting seeds and specimens to send, alive and dried, back to Petiver, Sloane, and the waiting audience of collectors.

Bradley was a skilled botanist and illustrator, as interested in the representation of specimens as in the specimens themselves. ${ }^{40}$ He spoke highly of the work of Maria Sibylla Merian, the great natural historical painter, writing that

\footnotetext{
${ }^{36}$ Ruysch's son, Hendrik, was also depicted as a child in Van Neck's The anatomy lesson (1683), shown holding a skeleton. David Mazierski, 'The cabinet of Frederick Ruysch and the Kunstkamera of Peter the Great: past and present', Journal of Biocommunication, 38 (2012), pp. E31-E40, at p. E36.

${ }^{37}$ As Eric Jorink describes, no fewer than five rooms of Ruysch's house were used to house and display his collection, for which he published ten catalogues from 1701. See Eric Jorink, Reading the book of nature in the Dutch Golden Age, 1575-1715 (Leiden, 2010), p. 320.

${ }^{38}$ Archibald Adams to Sloane, 30 Sept. 1707, BL, Sloane MS 4041, fo. 2, cited from Eric Jorink, 'Sloane and the Dutch connection', in Walker et al., eds., From books to bezoars, pp. 57-70, at p. 63.

${ }^{39}$ Richard Bradley to Petiver, 20 June 1714, Amsterdam, BL, Sloane MS 3322, fo. 52. On Bradley's imposture as a physician, see F. N. Egerton, 'Richard Bradley's illicit excursion into medical practice', Medical History, 14 (1970), pp. 53-62; see also F. N. Egerton, 'Richard Bradley's relationship with Sir Hans Sloane', Notes and Records of the Royal Society of London, 25 (1970), pp. 59-77.

${ }^{40}$ In 1712, Petiver mentioned Bradley in a letter to his colleague William Sherard, describing him as a 'young gentleman ... who can design very well, has already engraved severall Quarto Table of the Aloes Ficoides, \& other succulent plants, which I hope he will suddenly publish'. Petiver to Sherard, 26 Sept. 1712, London, Royal Society, MS 252, vol. 3, fo. 423.
} 
she had ' 3 times feasted me with the light of her curious paintings' ${ }^{41}$ Merian had visited the Dutch colony of Surinam with her daughter in 1699 to illustrate the process of insect metamorphosis, publishing her Metamorphosis insectorum Surinamensium in $1705{ }^{42}$

Bradley wrote to his patron of his activity in copying the collections of Ruysch, Merian, and others, even as he busily attempted to gather cuttings and seeds. 'Dr Ruysch visits me twice a day and brings me of his most curious subjects to copy', he said in October 1714.

I have done all the spice trees from specimens pickled which have yet their natural colour \& adorn'd them with insects \& other curiosities. The cabinet the Dr is about to dispose of consists of what can be done in anatomical preparations, all of them perfect \& well adorn'd, fowls, insects, \& what else is curious in most subjects. ${ }^{43}$

Two weeks later, Bradley wrote again to describe the living and embalmed specimens in Ruysch's collection, saying that he had

From a fresh specimen of the nutmeg tree with the fruit which is so well preserv'd that it still retains its natural colour - made a design with my best hand - and another from the clove tree with the fruit \& flower of which I have a good specimen with the fruit in spirits. ${ }^{44}$

Bradley listed the specimens he was in the process of illustrating-cinnamon, pepper, coffee, aloe - and his choice from the boxes of butterflies and other specimens that Ruysch sent to him to draw while he recuperated from an illness.

Ruysch was extremely motivated to offer specimens to Petiver and Sloane, through the medium of their agent. He would eventually sell his collection to Peter the Great in 1717, but in 1711 (when Petiver visited) and 1714 (during Bradley's visit), he was still hopeful of finding a buyer in Sloane or another British collector. Like Adams before him, Bradley wrote to Petiver to convey Ruysch's offer to teach him his embalming secrets:

He designs to give a good beginning for a cabinet with the manner how to preserve all sorts \& particularly in anatomy ... and through his favor to me I can construe he would gladly have what interest can be made that

\footnotetext{
${ }^{41}$ Bradley to Petiver, 4 July 1714 (n.s.), BL, Sloane MS 3322, fo. 58v.

${ }^{42}$ Kay Etheridge and Florence F. J. M. Pieters, 'Maria Sibylla Merian (1647-1717): pioneering naturalist, artist, and inspiration for Catesby', in E. Charles Nelson and David Elliot, eds., The curious Mr. Catesby: a 'truly ingenious' naturalist explores new worlds (Athens, GA, 2015), pp. 39-56, at p. 39. Petiver had written to William Sherard, then Consul in Smyrna, that he had received a letter from Merian, "Who tells me of a cargo she has for me from Surinam, from her daughter which she sent thither whilst I was in Holland, to buy Dr Hermans Museum, the greatest parts of which I brought with me for Dr Sloane \&c.' Petiver to Sherard, 26 Sept. 1712. On Merian, see also Schiebinger, Plants and empire.

${ }^{43}$ Bradley to Petiver, 24 Oct. 1714, Amsterdam, BL, Sloane MS 3322, fo. 78.

${ }^{44}$ Ibid.
} 
his majesty may purchase his cabinet; he designs to dedicate the catalogue to him \& has told me his secret of injecting bodies so as to recover them to that beautiful state we see them in his museum, particularly the boy of 14 year old which has been dead 18 years \& is now in as full beauty as when he was alive. ${ }^{45}$

The practice of preserving 'all sorts', as Bradley knew, was of particular value when those sorts could be kept in 'as full beauty as when alive'.

\section{VI}

The specimen moved between genres: it was given immediacy, rendered lifelike, through the collection (wet or dry), through metadata, through textual descriptions, through visual renderings, and through the imperfect, fragmentary, or unidentified. The garden was obviously one of the key private or institutional collection locations in which specimens were remediated from one format into another, seed or cutting into living cultivar. Bradley was attentive in his correspondence to his patrons' desire for specimens to plant in their gardens: Mary Somerset, dowager duchess of Beaufort, was a particularly interested consumer of boxes of specimens, as were Petiver, Sloane, and Robert Balle. ${ }^{46}$ Sloane and Petiver collected for the Chelsea Physic Garden, Somerset for her garden at Badminton, Balle for his garden at Camden House.

But Petiver's most urgent use for Bradley's specimens (and those of his other correspondents) lay in the production of his serial publications, the ephemeral Musei and Gazophylacii, issued in decades, that he sent with his agents to distribute to potential patrons, collectors, and other likely readers. He published catalogues for his correspondents: 'A very grateful thing', wrote Jacob Bobart from the Oxford Physic Garden of one of Petiver's list of the contents of the Chelsea Physic Garden. ${ }^{47}$ These publications acted to advertise both Petiver's collection and his network of patrons and collectors, the printed dedication labels designed to be cut out and tipped onto the sheet for their recipient. Petiver used the serials to entice collectors into correspondence, while also advertising new specimens in his possession. In all cases, the visual was an essential accompaniment to the textual description, rendering the presence of the specimens and collection for their reader and, in many cases, in preferable form to the jumbled and dishevelled set of specimens that visitors sometimes complained of finding in Petiver's actual premises on Aldersgate Street in London.

\footnotetext{
45 Ibid.

${ }^{46}$ Julie Davies, 'Botanizing at Badminton House: the botanic pursuits of Mary Somerset, first duchess of Beaufort', in Donald L. Opitz, Staffan Bergwik, and Brigitte Van Tiggelen, eds., Domesticity in the making of modern science (Basingstoke, 2016), pp. 19-40. Robert Balle, a merchant, proposed Bradley for membership of the Royal Society and was the recipient of many of his specimens for his garden at Camden House. See N. R. R. Fisher, 'Robert Balle, merchant of Leghorn and Fellow of the Royal Society (ca. 1640-ca. 1734)', Notes and Records of the Royal Society of London, 55 (2001), pp. 351-71.

${ }^{47}$ Jacob Bobart to Petiver, 20 Aug. 1713, Oxford, BL, Sloane MS 3322, fo. $29 \mathrm{v}$.
} 
The superiority of Ruysch's specimens - and of Merian's and Bradley's copies - were particularly appealing to natural historians, like Petiver, who were closely engaged in print. Not all visual evidence was created equal: 'cuts', or engravings, and Petiver's in particular, were often judged to be of inferior quality. In 1712, William Greene wrote to Petiver about his meeting with Antoine de Jussieu, keeper of the Jardin des Plantes in Paris. 'He is one of the most jealous men alive', wrote Greene, nervously apologizing for Jussieu's contempt for Petiver's publications. 'His objection against your English herbal was the smallness of the cuts, and in your Gazoph: Nat et artis the fault lay in the graving. ${ }^{48}$ Cheaply printed with scattered engravings, Petiver's miscellanies were not infrequently despised by their continental recipients. ${ }^{49}$

In this context, preservation in spirits offered several significant advantages, both material and epistemological, to natural historical practitioners. Spirits immobilized the specimen, capturing it both in time and within a fixed space, the glass in which it would be endlessly and reliably visible to its observers. As Ruysch's preparations reveal, the skilled 'embalming' or 'drowning' could ensure the retention of a living colour, a persuasively lifelike appearance. The specimen - inert, 'balsamic' - was able to act as synecdoche of its broader natural historical category, to be available, on demand, to resemble the living example that was so often unattainable or unmanageable in the broader natural historical environment. Spirits, as medium of preservation, enabled the translation of natural historical object into specimen - one, moreover, both persuasive and inert enough to be easily translated into print culture. Ruysch's embalmed specimens, with their re-purposed anatomical and botanical decorations and ornaments, achieved their greatest and longest-lived influence in print, captured in spirits, in jars, in the pages of his catalogues.

As Boyle had argued, preservation in spirits created the essential natural historical quality of 'readiness', the ability to be used, on demand, for observation. He wrote of his specimens in spirit of wine, 'Which I did that so I might have them in readiness, to make on them, at any time, the observations, I thought them capable of affording; and to let my friends at other seasons of the year, see. ${ }^{.50}$ It was through its capacity to make 'ready', to preserve and activate the biological commodity as natural historical specimen, that alcohol facilitated European imperialistic collecting. In the 'spirits and glasses' of virtuosic display, alcohol was also used to publish and disseminate those

\footnotetext{
${ }^{48}$ William Greene to Petiver, 3 Aug. 1712, Paris, BL, Sloane MS 3322, fo. 27.

${ }^{49}$ See Uffenbach's description of his visit to Petiver. Jacob Bobart showed the proposal for the English herbal to 'several ingenious persons' in Oxford: 'they commonly seem to intimate that they have Mr Ray's Synopsis already, and that [Petiver's] scents too much of plain English, for their literate palates to digest'. Bobart to Petiver, 20 Aug. 1713, BL, Sloane MS 3322, fo. 29r. Greene found the same response in Paris, writing to Petiver to say that 'as for subscriptions [to the English herbal] I have not yet got any among the French and doubt much if I can for they spake not English and are not able to make any use of your English Plants'. Greene to Petiver, 3 Nov. 1713, Paris, BL, Sloane MS 3322, fo. 34r.

${ }^{50}$ Boyle, 'A way of preserving birds taken out of the egge', p. 200.
} 
specimens, to render the products of European imperial expansion 'lifelike', preserved 'in liquore Balsamico'.

Acknowledgements. This article forms part of Intoxicants and early modern European globalization: spaces, practices, material culture, a special issue resulting from a workshop series, held in 2017 at the Victoria and Albert Museum and in 2018 at the Beinecke Library, Yale University. I am very grateful to the ESRC and the Beinecke Library for their support, and must also thank my co-editor, Phil Withington, the participants in the workshops, and the contributors to this issue for the opportunity to take part in such an intellectually generous project.

Funding Statement. The workshop series at the Victoria and Albert Museum was funded by the ESRC 'Intoxicants \& Early Modernity Project'.

Cite this article: James $\mathrm{K}$ (2022). The Intoxicant as Preservative and Scientific Instrument in the World of James Petiver. The Historical Journal 65, 91-107. https://doi.org/10.1017/ S0018246X21000248 